\section{Slowmation Application in Development of Learning and Innovation Skills of Students in Science Course*}

\author{
Nurhan Atalaya ${ }^{a, * \star}$, Ş. Dilek Belet Boyacı ${ }^{b}$
}

\author{
Received: 27 March 2019 \\ Revised: 13 May 2019 \\ Accepted: 20 June 2019 \\ ISSN: 1307-9298 \\ Copyright (C IEJEE \\ www.iejee.com
}

DOI: 10.26822/iejee.2019553347

\begin{abstract}
The objective of the present study is to determine the effect of the process of designing a slowmation (SMA) on the development of $21^{\text {st }}$ century skills of "learning and innovation" in 4th grade science class "Light and Sound" and "Planet Earth" units. Study group included 44 students attending $4^{\text {th }}$ grade in two private schools in Southeastern Anatolia region. Four female and five male, a total of nine focus students were determined in the study group where the application was implemented. The study was conducted in 17 weeks (51 periods), out of which six weeks spanned the pre-application process and the application lasted for 11 weeks. Different data collection tools such as video records, semi-structured interviews, group audio recordings, $21^{\text {st }}$ century learning and innovation skills scale $r$ and student diaries were used to collect data in the study. Quantitative data were analyzed and interpreted using SPSS software. Qualitative data were analyzed with descriptive analysis. Overall results of the study demonstrated that slowmation application resulted in the development of $21^{\text {st }}$ century learning and innovation skills, namely creativity and innovation, critical thinking and problem solving, collaboration and communication skills.
\end{abstract}

Keywords: Science Course, $21^{\text {st }}$ Century Skills, Learning And Innovation Skill, Slowmation, Primary School

\section{Introduction}

In $21^{\text {st }}$ century information society, expansion of knowledge, becoming available for the masses and the necessity of different cultures to live together resulted in individuals to encounter more technological, economic, social and cultural changes along with the phenomenon of globalization. Thus, it is expected of individuals to adapt to changes and continue their lives, follow the technological advances, be able to select and analyze the information within the bulk of knowledge that is produced and circulated rapidly, use the information they collected in their daily lives and transform the information into products.

This change and transformation make it possible for the individuals to access information faster, use the information they accessed in their daily lives, and find solutions to several problems they encounter. In the present century, what is significant is now how individuals access the information, but how they would analyze and utilize the information they access in their social lives. Thus, the expectations from the individuals change in the $21^{\text {st }}$ century as well (Wagner, 2008).

The skills and competences that the individuals should possess in $21^{\text {st }}$ century are called $21^{\text {st }}$ century skills. $21^{\text {st }}$ century skills do not involve only skills or knowledge. $21^{\text {st }}$ Century skills include understanding and performance. In other words, it is a concept where knowledge and skills are blended (Dede, 2009). 21 $1^{\text {st }}$ century skills, where knowledge and skills are used in conjunction, are skills that are necessary for individuals to lead more quality lives, solve the problems they face more easily, perceive and analyze the events in society through different perspectives and to attain more success in their professional and social lives. Different institutions classified $21^{\text {st }}$ century skills in different ways. According to P21 (2009), $21^{\text {st }}$ century skills are learning and innovation, life and career, knowledge, media and technology skills; according to NCREL, they are creative thinking, active communication, high productivity, and digital age literacy; according to ATCS, ways of thinking, ways of working, and tools of living and working in the world; according to NETS/ ISTE, creativity and innovation, critical thinking, problem solving and decision-making, communication and collaboration, digital citizenship, technological applications and concepts, research and information fluency; according to EU, learning how to learn, communication, cultural awareness, social and citizenship competency, entrepreneur sensibility, digital competence; according to OECD, interaction with heterogeneous groups and use of technology tools. Although the $21^{\text {st }}$ century skills were classified differently, there are similarities among these groups. $21^{\text {st }}$ century skills focus on creativity, critical thinking, collaborative work and problem solving. Individuals could achieve $21^{\text {st }}$ century skills classified under different topics throughout all educational steps from primary school to higher education. Education should train individuals that could meet the demands of the $21^{\text {st }}$ century and cope with the problems of that new age (Tutkun, 2010). Thus, it could be stated that acquisition of $21^{\text {st }}$ century skills could be considered as the primary goal of primary school curricula in preparing the children of today for the future. One of the basic courses where $21^{\text {st }}$ century skills could be acquired is the course of science.

Science curriculum focuses on students to be individuals that integrate and comprehend the skills, attitudes, values, understanding and knowledge on fields of science to develop research-examination, critical thinking, problem solving and decision-making skills, become lifelong learning individuals, sustain their curiosity about their environment and the world (Efendioğlu 2012; MEB, 2005; Ürey \& Çepni, 2014). In the educational process that would be designed to enable students to reach these goals and objectives described in the curriculum, it is quite important to utilize multimedia simulations. Because, multimedia simulations do not only facilitate students to reach cognitive goals and objectives, but also develop their affective traits that they would require in learning and teaching processes such as attitude and self-efficacy (Efendioğlu, 2012). Furthermore, it is significant to use

*This study was produced from the PhD dissertation titled "Applying Slowmation in Science Lesson to Improve Students Learning and Innovation Skills". This thesis study was supported by Anadolu University. Project Number: 1407 E358

${ }_{a, * *}$ Corresponding Author: Nurhan Atalay, Niğde Ömer Halisdemir University, Faculty of Education, Niğde, Turkey. E-mail: nurratalay@gmail.com

bŞ.Dilek Belet Boyacı, Anadolu University, Faculty of Education, Eskişehir, Turkey. E-mail: sdbelet@gmail.com 
educational technology tools in science classes to enable students to achieve a versatile understanding of events and objects, ability to interpret these, develop their creativity and to maintain their interest in the class (Akpınar, Aktamış \& Ergin, 2005). There are several technologies that are used or could be integrated in science education such as the Internet, simulation, probe-ware, multimedia and hypermedia (Alkan, 2011). Integration of technology in different perspectives in the education resulted in different learning-teaching approaches. Especially, one of the effective learning-teaching approaches used in science instruction is slowmations (Keast, Cooper, Berry, Loughran \& Hoban, 2010). Animations could assist students to imagine the phenomena that occur in science courses and abstract knowledge shaping as concrete conceptions in students' minds (Atılboz, 2004). Design process of slowmation includes first the production of the models and later creation of digital photographs that reflect small sequential movements of these models to obtain an animation effect, and the process is concluded with transfer of these digital photographs into a digital video software (Kervin 2007). Slowmation simplifies the complex process of animation creation and provides an opportunity for primary and middle school students to design their comprehensive animation on scientific concepts (Hoban, 2005, Hoban \& Ferry, 2006, Hoban, 2007; Hoban, 2009). The most particular characteristics of slowmation is that there are only two frames per second, not 24 frames per second like in computer animations. Because, here the purpose is not to present a story, but to demonstrate and explain a scientific concept (Hoban, 2007). Slowmation is the creation of digitally shot and manual controlled model photographs with the stop-motion technique (Laybourne, 1998). Slowmation process includes four phases of planning, where learners research how they would present the concept or subject that includes the changes and where the tasks are shared; narration, where the stories that support the investigated, selected and developed subject; production, where models are constructed and photographed; and reproduction, where digital pictures are uploaded into a computer and sequenced, and transferred into a computer software and turned into an animation (Hoban, 2007) Especially the increasing use of digital technologies in science education makes it possible for the students to present the content in different ways. For instance, students could present scientific concepts using two- or three-dimensional videos or animations with short stories. Ability to show the same concept in different ways would enable students to reflect their thoughts in the content. Furthermore, the ability to reflect their thoughts in the content would promote students' creativity (Hoban, Loughran \& Nielsen, 2011). In addition, if students are encouraged to explain and share scientific concepts with their peers, they would also acquire communication and presentation skills (Hoban \& Nielsen, 2013). Although there are international studies on the utilization, production and effects of slowmation in the learning-teaching process, no studies that scrutinized the approach were conducted in Turkey. The objective of the present study is to determine the effect of slowmation application on the achievement of $21^{\text {st }}$ century "learning and innovation" skills by the students attending primary school $4^{\text {th }}$ grade sciences course. Thus, the following research question was determined:

- How students use and improve $21^{\text {st }}$ century learning and innovation skills in slowmation creating process during $4^{\text {th }}$ grade science course?

\section{Method}

\section{Research Model}

The present study aimed to determine the effect of slowmation application on the achievement of $21^{\text {st }}$ century "learning and innovation" skills in primary school $4^{\text {th }}$ grade physical sciences course was conducted with a mixed method, where qualitative and quantitative methods were used together. Mixed methodology is the use or blending of qualitative and quantitative research techniques, methods, approaches or concepts in an integrated manner in a particular study (Creswell \& Plano Clark 2006; Creswell, 2009). In the present study, embedded experimental model of mixed methods based on qualitative data, supported by quantitative data, and quantitative-qualitative method variation based on dominating status paradigm emphasis was utilized. In this design, a study based on qualitative or quantitative data attempts to answer the research question, while utilizing quantitative or qualitative whenever needed (Plano Clark et al., 2008). The quantitative part of the study was designed based on the empirical design of pretest-posttest with control croup. One of the two groups determined randomly was used as the study, and the other as the control group. Pretest and posttest measurements were conducted in both groups in this model. Based on the research question, quantitative data were used in the beginning and at the end of the empirical study, and qualitative data were collected with semi-structured observation, interview, video and audio recordings, student and researcher diaries and document analysis, so that qualitative and quantitative data would complement each other, and thus, a more valid and reliable data were obtained.

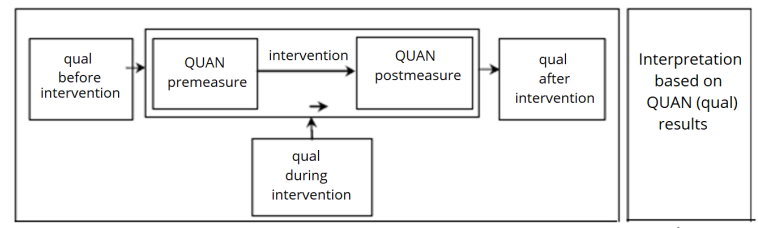

Figure 1. Embedded Experimental Model (Creswell \& Clark, 2007)

\section{Participants}

Participants of the present study included $4^{\text {th }}$ grade students attending two schools located at a city in Southeast Anatolia in 2014 - 2015 academic year fall semester. A draw was conducted among $4^{\text {th }}$ graders to determine the study and control group members. The class 4A with 22 students was determined as the test group and the class 4A with the same number of students was assigned as the control group. The study was conducted with $4^{\text {th }}$ graders because this class level was suitable for the achievement of the skills such as critical thinking, problem solving, creativity, collaboration and communicative cooperation, determined as $21^{\text {st }}$ century skills in literature, when cognitive development levels of the students are considered.

Selection of the participants for the qualitative part of the study was conducted with criterion sampling, one of the purposeful sampling methods. Purposeful sampling allows in depth study of situations that are assumed to contain vast information (Yıldırım \& Şimşek, 2008). Purposeful sampling is widely used in qualitative research for the identification and selection of information-rich cases related to the phenomenon of interest (Palinkas et al., 2015). Attending the $4^{\text {th }}$ grade in a middle socio-economic level school was the main selection criterion for the students in the current study. In the study, a total of 9 focus students, out of which four was low level, three medium level and two high-level, were determined based on the data obtained after pre-application observations, and the interviews conducted with the students identified based on the scores they received in " $21^{\text {st }}$ Century Learning and Innovation Skills" scale were selected. Number of focus students was determined based on the classroom size and mean scores the students received in the scale. The names of focus students were coded for ethical reasons. 


\section{Data Collection Tools}

In the study, which was designed in embedded experimental design, necessary data to respond to the research question were collected with researcher and student diaries, semi-structured interviews, video and audio recordings, and student products. Furthermore, in the quantitative section, "21 $1^{\text {st }}$ Century Learning and Innovation Skills" scale that developed by researchers was utilized. Draft scale consisted of 60 items. Opinions of five experts in the field were consulted on the draft scale. The experts scrutinized the items based on their suitability for the dimension, comprehensibility of the expressions, whether the items concerning the skills under each dimension reflected all the characteristics of the related skill, and whether these were suitable for fourth grade students. As a result of expert assessments, four statements that were not suitable for the level of students and comprehensibility of the statements were excluded from the scale, while five statements that did not reflect the related skills completely were edited. To determine the answering duration and comprehensibility of the scale, the 56 -item scale was applied to 30 fourth grade primary school students in the pre-test stage. As a result, two statements that were not understood clearly by the students were edited. 56-item draft scale was thus finalized. During the following phase, the scale was applied to the students and scores obtained from the scale were analyzed. Exploratory factor analysis was conducted on obtained data to determine the structural validity of the scale. In this process, primarily Kaiser-Meyer-Olkin (KMO) and Bartlett Sphericity tests results were examined, followed by the common factor variance values for the items, eigenvalue line graph, principal components analysis results, and "verimax" rotation technique results, conducted to obtain interpretable variables. As a result of the interpretation of the above-mentioned data, the scale was finalized. Cronbach alpha reliability coefficient of the scale, where 39 items were grouped under three factors, was determined as $\alpha=.955$.

\section{Implementation Process}

Slowmation application conducted in primary school sciences class was instructed within the context of $4^{\text {th }}$ grade "Light and Sound" and "Planet Earth" units. Both units were redesigned to comply with slowmation application. Slowmation application lasted approximately 11 weeks. The first week of the study was reserved for the instruction of the slowmation application. For two class periods, information was presented to the students on how to produce animations and for one class period different animations produced on different subjects were presented as samples. Thus, the students had a preliminary idea on what kind of an application they face and what they could do with the application. In the test group, students produced two slowmations per subject determined based on the course syllabus. They researched and structured the information in the planning stage and then transformed the information they obtained into a story in the narration stage. When the story was ready, the production stage where the story was animated with models was initiated. After the models were created, the models were set in motion with photographs in the same stage. In the final stage of reproduction, students differentiated their animations by voicing over the stories or applying different effects to the animations. In that stage, the products were assessed by the teacher and other group members in the classroom. In every stage of the slowmation creation process, the students were evaluated using classroom observation form. Furthermore, at the end of each unit, interviews on the process were conducted with determined focus students.

\section{Data Analysis}

$21^{\text {st }}$ century learning and innovation skills scale was used as quantitative data collection tool. Obtained qualitative data were analyzed based on the objectives of the study to solve the research problem. Statistical analyses were conducted with SPSS software. For the analyses, arithmetic mean and standard deviation of participating students' pretest and posttest scores were calculated. To respond the research questions, in-group comparisons were conducted. In-group and between-group comparisons were conducted with t-test. Descriptive analysis technique was utilized in the analysis and interpretation of qualitative data in the study. In descriptive analysis, obtained data are summarized and interpreted based on pre-determined themes. Data could be organized based on the themes identified by research questions, or could be presented with respect to the questions or dimensions identified during the interview or observation processes. Frequent direct quotes were used to reflect the views of the observed or interviewed individuals (Yıldııım \& Şimşek, 2008). Collected application data were regularly analyzed in the present study. At the end of the study, all collected data was readdressed using descriptive analysis and the relationship and consistency between the collected data that was collected throughout the study were scrutinized.

\section{Findings}

In this section, learning and innovation skill development using slowmation was examined in every stage of the application. For this purpose, the class of 22 individuals was divided into four groups (5-5-6-6). Planning, narration, production and reproduction stages of the application were conducted with the achievements depicted in the related units of the sciences course in mind. Each stage was assessed based on learning and innovation skills (creativity and innovation skills, critical thinking and problem-solving skills, and communication skill).

During the first and planning stage of slowmation creation, students could research a particular subject or concept or the teacher could assist students in learning a subject or concept by structuring it for the students. In the planning stage of the present study, research questions about the subject within the framework of the achievements of sciences course were presented by the teacher. The information was structured in classes shaped around these research questions. "Learning and innovation skills" that students used and developed in the process in each stage are presented in Table 1.

\section{Planning Stage Findings}

In planning stage, sub-skills such as "taking notes, producing solutions, wondering, reading and research, imagining, using new technologies, following up scientific journals, creating products," where "creative and innovation skills" were utilized and development of these skills was identified, were determined.

The author noted the finding that students were not able to take notes in the researcher's diary as follows: I asked students to observe light sources by projecting light on the mirror, reflector, aluminum folio and iron spoon both in darkness and in ambient light and write the results in their notebooks. Furthermore, I asked whether the moon and stars were light sources. I asked them to research the answers and write the findings in their notebooks. However, most of the students asked me to write the homework at the board. They have copied what I wrote on the board to their notebooks. In fact, Berk asked what to write as the 
Table 1. $21^{\text {st }}$ century learning and innovation skills that students used and developed during the process

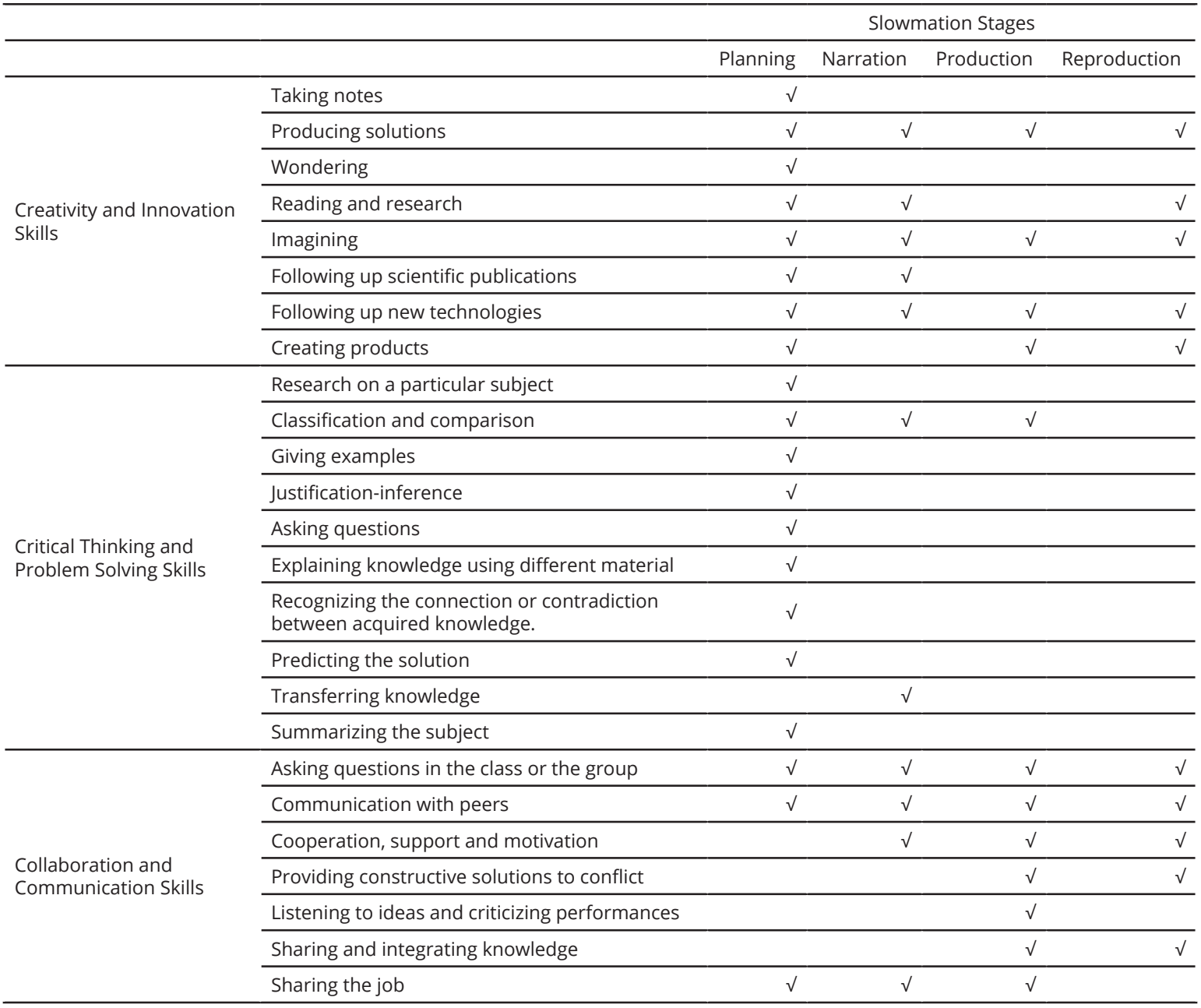

title of the homework. However, the expressions of the students in entries dated the following days in their diaries that show they have started to use this skill are as follows. Berk wrote; I wrote down all information I searched at the Internet. I brought the notebook to the classroom. Since everyone wrote down, too, we were all had common knowledge; Irmak wrote; I researched and also printed it out. But, since the teacher would not allow me to read, I underlined the passages that I would explain as such. I will talk about these findings; Aras wrote; I researched as well, but did not write it down. If I take note in small headlines, I remember them better. I took notes like that. Student statements showed that they have used and developed the skill in the process. It was observed that students obtained information and came up with different solutions to problems they encountered. Researcher's observations and student statements show that students wondered about things and conducted research, gathered information and then asked their questions accordingly during the planning stage. Berk said; There are these things on mount Nemrut, the heads, they are cold during the night, and when the morning comes, they crack. In the evenings, they get cold again as a result of things like rain and become stone again. Could this be an example of erosion? Because, when they crack, they fall off. When I visited there, there were stones like that around. It was determined that students conducted reading and research out of given subjects albeit limited at first, but increasingly as the time passed in the planning stage. It was observed that students who were surprised with an example from the book presented by the researcher started to give examples from different resources in the classroom after that event.

In the interview conducted with students at the end of the unit, they stated that they have used various resources in the research process. Eda; For instance, I read some books. I learned a lot from these books. In fact, I don't like reading much. But, when I started researching I wanted to look at everything continuously. Some, we had at home. Some others, I bought anew. Researcher took the following notes on the diary about the change in student's behavior later on: I liked the way students shared information and they studied the subject they researched very well. Now, they could freely read about what they search for and even could tell about it using their own words. Can showed me the visual dictionary he bought from TÜBITAK publications. Mehmet also said he liked it very much and would like to buy it as well. Enes and Tolga came to me in the recess and asked me where they could buy such books. This week TÜBITAK press would open a stand at school. They have never came before, this would be their first time. Students showed quite an interest. The attendant at the stand told me he had sold a lot of copies of the book on light to the class I teach. I was really happy. In planning stage, students demonstrated their creating a product skills partially or effectively with the drawings they created.

In addition to creativity and innovation skills, it was determined that "critical thinking and problem solving skills" were also used and improved in the planning stage as evidenced by skills such as "conducting research within a subject matter, classification and comparison, giving examples, justification-inference, asking questions, explaining the knowledge using different material, recognizing the connections or contradictions in obtained information, predicting solutions, and summarizing the subject." It was determined that students conducted research 
based on a subject given by the researcher in the planning stage. During this stage, students conducted research and shared the results in the classroom. It was observed while the students shared their knowledge that they have read about the subjects they researched and their research was not incidental. Thus, it could be argued that their research was purposeful. Students reflected the fact that they conducted research to access more information in their diaries as follows: Esra; I completed my homework today by doing research in the books. When there was a shortcoming I first asked my mom and then searched the Internet. Doing such a homework was great fun. Finally, I finished my homework. Tolga; I find the results of the homework teacher gave by searching the Internet and completed my homework by accurately noting down the things I found on the Internet. I will go to school tomorrow with my homework completely finished.

In the interviews, students expressed similar statements. Berk; I did my homework using the Internet and books. First, I browsed the net to collect information about it. I took notes on paper. I searched the Internet. I printed them out on the printer. I checked the resources at home and textbooks. I combined the information I gathered. I printed out pictures as well. It was identified that students were not able to use classification-comparison skills in the initial process in planning stage, but developed it during the process. It was observed that the students, who did not even understand the question about classification, demonstrated improvement later on. Later in the process, a conversion in the classroom was realized as follows: Irmak; while other lamps turn most of the energy into heat, fluorescent bulbs, on the contrary, convert all the power into light. Fluorescent bulb is economic; they consume less energy. However other bulbs are not like that. They consume a lot of energy. In addition, other bulbs get heated a lot, but, in my opinion, fluorescent bulbs do not get warm a lot. Enes; fluorescent bulbs provide more illumination than regular bulbs and are more economical. Gonca; fluorescent bulbs radiate more light, while regular bulbs radiate a lot less. Eda; while regular bulbs consume a lot of energy, fluorescent bulbs consume little energy.

It was identified that students utilized and developed "collaboration and communication skills" and sub-dimensions such as "asking questions in the classroom of the group, communicating with peers and task sharing" in the planning stage. In the planning stage, students are expected to communicate with each other by asking questions about the subject they research. Eda and Mehmet, two students from the third group asked about the things they were curious about or stuck in their minds about the Planet Earth unit to their group members. The conversation among group members was as follows: Eda; When we pour water on the soil, does it go into the underground water? Ece; I mean; this water is then used after treatment. They treat water the same way in places where the water is polluted. Mehmet; When it rains, I mean it rains too much, when the underground waters increase a lot, would 4/4 be covered? It was determined that students asked questions in the group and the classroom and developed these skills by using them in the process. While groups experienced communication problems in the beginning, as time passed by, they have resolved this problem. Students wrote the following on the subject in their diaries: Esra: We have poor communication in the group, no one listens to others. I think we won't be able to complete the animation in time. In the upcoming stages of the process, Eda; Everyone expressed their ideas in the group. Then we selected one of them. We decided to create a story by adding little by little from some of these information or all of it. Thus, research done by all will be used. We will combine them all to write a story.

\section{Narration Stage Findings}

It was determined that students utilized and developed "creativity and innovation skills" in the narration stage and the sub-skills of "producing solutions, reading and research, imagining, using new technologies, and following scientific journals" were identified. While students did not use these skills in the Light and Sound unit, it was determined that they utilized these skills in the Planet Earth unit. It was also determined that, as an alternative to narrating the animation as a story, students thought about narrating their stories as a poem and produced a different solution. Eylül stated the following in the interview conducted at the end of the unit: Since the subject was the earth, we named our characters as star, sun, etc. Then, primarily Merve did the research, and everyone shared the information they researched, and then I wrote all by hand. We tried to transform the information into a poem. That idea to write a poem occurred to us. At first, we just thought about it. We tried to provide different information than what everyone knew. Since the students thought about different ways of expression when creating their models, they differentiated their narratives based on the models they created as well. Thus, they altered their stories based on the models they created. Middle level focus student Eda expressed her opinion on the subject as follows: First, in the lithosphere, Gonca wanted it this way, then we made additions, we added a lot of information to make it better. For instance, when building models, we first think this should be in the story as well, and then we decide it would be in the story. In fact, when we were creating the models our story changed, but it became better. When creating their stories, it was identified that they have referred to the information they collected while reading and researching in the planning stage, and did research when they require further information in this stage as well.

In narration stage, it was found that "critical thinking and problem solving skills" were utilized only at the level of classification and comparison and transfer of knowledge and developed during the process. The fact that students compared their products within the context of classification and comparison was exhibited in the interviews with students. Eylül; In fact, I wanted to share a lot of information, but then it became too long. Then, we briefly talked about the layers and volcanoes. A little bit about erosion We explained landslides due to erosion. In our last animation, there was not much information, and hence, we tried to provide as much information as we could in this one. It was also identified that students transferred the knowledge they acquired from different resources into their stories. Esra summarized this fact as follows in her diary: On the poster in "Lemon Office supplies," there was a great text. I received help from that one.

In narration stage, it was determined that students utilized "collaboration and communication skills" and development of these skills were observed in students and the following sub-skills were identified: "asking questions within class or the group, cooperation, support and motivation, communication with peers and division of labor." In narration stage, students are expected to ask questions to each other, communicate while completing their stories when writing a story on a subject of research as a group or in the classroom. Students asked the following questions about the subject: Berk; Teacher, can we do this in the form of funny stories? Eda; Will we include all information we could find? Eylül; For instance, teacher, you have given an example. There was Cedric, can we create characters like him? Esra; Should we narrate Edison's life or the bulb, which one would be better? Berk; Let's start with Edison, and at the end we could say that he invented the electric bulb. At that date researcher made a note about this in her diary as follows: Students completed the first story in 
the unit today. I observed that students tried to avoid the mistakes they did in the previous unit. They wrote stories where they could implement simpler models. Different from the previous one, they wrote the stories after serious consideration and asking many questions to each other to improve their stories and animations. As in other stages, groups members are expected to share the tasks between them and fulfill their responsibilities effectively in the narration stage. It was observed that the groups were not able to fulfill the given tasks completely in the beginning of the process. Students in the same group reflected their views on the failure of division of labor in the beginning of the process in their diaries as follows: Yasin; Task sharing failed a little. Because, no one listened to what others had to say. We were not able to do anything in the class today. Esra; Even we shared the tasks, everyone expects me to do everything. I don't understand why we are a group in the first place. We are behind all groups. We have to work very hard. In the forthcoming stages of the process, students stated in their diaries that they have finally managed to share the tasks and fulfilled the responsibilities of the assigned tasks as follows: Irmak; They elected me the group president to assign tasks. We gave a task for everyone. Sometimes we make something like a meeting. For instance, when we assign a task to someone, it won't work, and I check it out. But, now, I can say that everyone does what they are assigned.

\section{Production Stage Findings}

It was determined that students utilized and developed "creativity and innovation skills" in the production stage and sub-skills of "producing solutions, using new technologies, imagination and creating products" were identified. To prevent students to limit themselves, sufficient amounts of material (construction paper, crayons, marker pens, playdough, glue, etc.) and time were made available in this stage. Each student came up with different suggestions about creating the models in this process. The following is a sample of student communications: Berk Let's draw first, and then cut and paint. Let's do something like this, and then glue something like that on the back, so we could make them move like shadow puppets. Celal; We could do something else as well. We could photocopy Edison; it would be more realistic. And then we could glue it to the stick. But, this one is too small, it needs to be bigger. Yasin; We could put the models on the stool, it would create a background and pictures would have better focus. It was observed that students proposed different solutions to problems they faced. It was also observed that students worked together to resolve the problem and complete the stage without any problems. On another conversation between the students: Beren; We could do it on a A4-size paper, too. As you can see, we experience problems in setting the birds in motion. Eylül; In my opinion, if we do it two-dimensional, using a drawing like this, don't you think we could set it in motion more easily? Beren; We can even do our Carettas like that as well. Let's make them all the same. We can even do the following; we can attach speech bubbles, can't we? Can; It would be super, then we don't even need to talk. It was determined that students utilized imagination skills when producing solutions. It was determined in the beginning of the production stage that students had limited skills in using new technologies but they have developed these skills in the process. Researcher reflected this process in her diary as follows: I provided a camera and a tripod to the students. But I observed that they were not able to use the tripod, holding it in the air and not fixing it on the ground, or did not use it when focusing the photographs. Then, I visited each group to show how to use it. They experienced a few problems even after that but, in a short while all the problems were resolved. It could be stated that each group was able to create the models about "Light and Sound" and "Planet Earth" subjects and animated them and completed the process of taking photographs at the end of the production stage, demonstrating creating product skills. Although several problems were encountered at the beginning of the process in creating products, they have resolved these problems after a while. Students reflected this process in their diaries as follows: Berk; Since we could not write down our story fully, we lost the order of things when taking pictures. We left it the way they were, to be ordered later on. Melek; Since we left our story unfinished, we were not able to finish this as well. Because, we had missing photographs. Researcher wrote the following in her diary about students creating products: Students worked with great will and effort. In fact, they wanted to complete the task of taking photographs without even taking a break. Today, all students completed the task of taking photographs. It was determined that students used "classification-comparison skills" that are considered among critical thinking and problem-solving skills in both units in the production stage. It was also determined that students compared their products in conversations they made within their own groups and with other groups in the production stage. Students reflected the following in their diaries in this process: Aras; The models of other groups are nice, but ours is nice as well when compared to them. Eda; Our models have many superior features. For instance, they are three-dimensional and have several furnishings. Mehmet; Ours look like real, the others not so much. It was determined that students utilized and developed "collaboration and communication skills" in the production stage and sub-skills of "asking questions in the group and the classroom, communicating with friends, resolving conflicts constructively, cooperation support and motivation, sharing and integrating knowledge, listening to ideas and criticizing performances" were identified. Students who experienced problems when photographing the models asked questions to the researcher and to each other. A dialogue between the researcher and students was as follows: Aras; When I take them like this, it comes out too small. Enes; Let me have a look. I think we need to put this a little bit higher. Aras: Also, since the flashlight goes off, it becomes indistinct. Enes; I think we should ask the teacher. Aras; Teacher, we cannot focus this, and the ground is visible, how should we proceed? In this stage, it was observed that group members communicated with each other on issues such as how the models should be or the process of taking photographs. Tolga reflected the communications in the group as follows in his diary: Some of us share their opinion about the objects in the group, altogether Because of this, we created very beautiful models and took their pictures. Students explained in-group communications during the interviews.
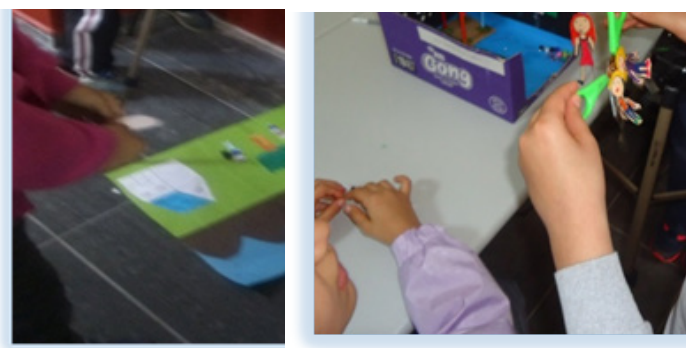

Photograph 1. Photo relating to creation process

\section{Reproduction Stage Findings}

In the reproduction stage that was the final stage of slowmation production process, it was determined that students utilized and developed "creativity and innovation skills" and sub-skills of "producing solutions, reading and 

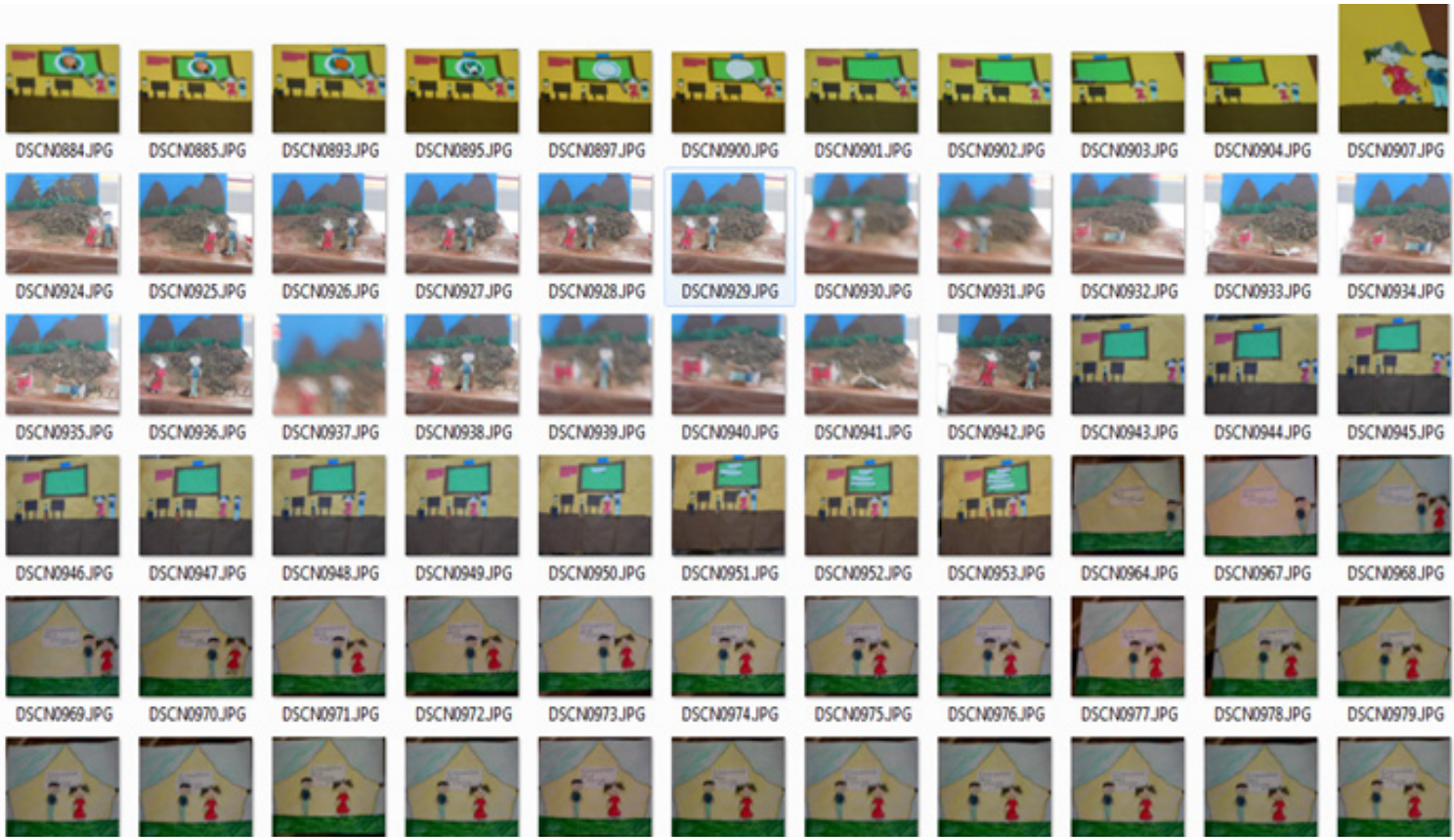

8

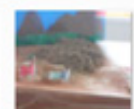

DSCND904.JPG

DSCND907.JPG
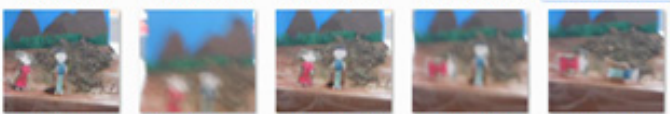

DSCNO930.JPG

DSCNO931.JPG

OSCN0932.JPG
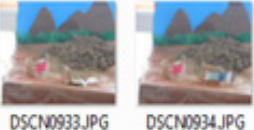

DSCND98SJPG

DSCNO937.JPG

DSCNN938.JPG

DSCND939.JPG

DSCND940.JPG
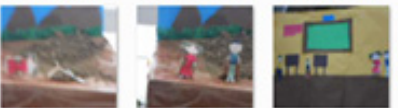

DSCND933.JPG

DSCND934.JPG
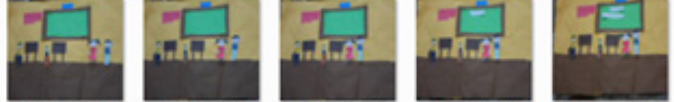

OSCAN941.JPG

DSCNOS42.JPG

DSCN0943.JPG
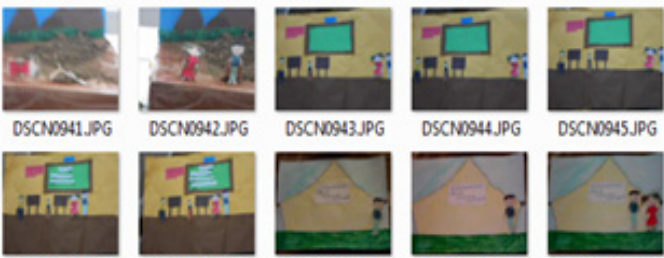

DSCNDS4.JPG

DSCND945.JPG

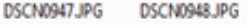

DSCND949.JPG

DSCND950.JPG

DSCND951.JPG

DSCN0952.JPG

DSCND953.JPG

DSCN0964.JPG
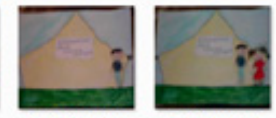

DSCND967.JPG

DSCND968.JPG
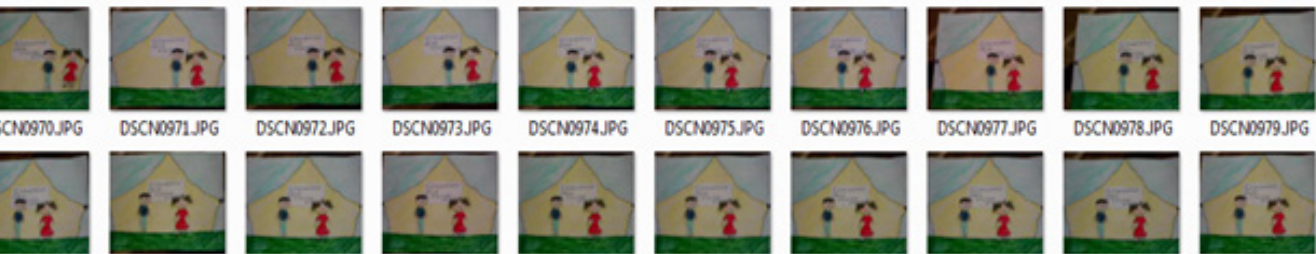

Photograph 2. Photo folder of the generated animation

research, using new technologies, imagination and creating products" were identified. It was determined that students had proposals about missing photographs and views on producing animations using different methods. Furthermore, it was observed that each student expressed her or his ideas about the problems they faced. Different solutions developed by the students to improve the animations of other groups after the presentations were as follows: Tolga; They did not provide much information. Also, they could have used the material better. Beren; There could be more photographs and colors. Also, they had less number of photographs. They should have taken more. Irmak; I think it is not good, because they did not share the tasks well. If they had worked together better, it could have been better. Berk; This does not look good, because it's black and white. It could have been more lively if they had used colored pens. Also, the number of photographs are not enough, it could have been more. It was determined that students investigated SMA program and other related programs. Here are some of the conversations between the students on the subject: Aras; Teacher, do you remember what you explained, that thing, movie maker, I asked my father about it. And he showed me. Eda; I checked out the Internet, there was a video showing how it works. But they wrote there that it was a film making program. Aras; It is, but what we do is short animation, isn't it so teacher? Certain students stated that they have investigated movie maker software and found different features about the software. The following is an example of student conversations on the subject: Eda; We have found another place on the timeline after we added the pictures here. Mehmet; Yes, teacher, there is this place where the photographs are, when we move the cursor there, we can extend and shorten the time there. It was determined that students did not research what they should do to color, differentiate and enrich the animations in this stage. Aras wrote the following in his diary about the subject: We added the sound of lightning that we downloaded to the computer at school to the lightning we drew. Our work was different and very nice. Finally, we adjusted the time and our animation was ready. It was identified that students used new technologies related to the subject when transferring the photographs to the computer, editing and combining the photographs and using the animation software.
It was determined that students did not use "critical thinking and problem solving" skills in the reproduction stage. In this stage, it was also determined that students utilized and developed "collaboration and communication skills" and sub-skills of "asking questions in the classroom or in the group, communication with peers, resolving conflicts constructively, cooperation support and motivation, sharing and integrating knowledge" were identified. It was also determined that students posed questions on editing the photographs, making them look better and use of movie maker software to each other and the researcher. The following are examples for these questions: Aras; Teacher, we want to edit these photographs. It happened, the floor is visible. Can we cut this at the sides like we do in Facebook? Aras; In fact, as I did with the one before, I cut it like a slide. It is very easy. Can we do it that way? Irmak; But then we cannot add our voice. We cannot adjust the time. This program is fine. Let's continue. Enes; We learned it anyway. This is easy too. But first, we have to edit the photographs, don't we? It was observed that the students in the first group got along with each other better and spent efforts to complete the stage with success in the first unit towards the final stages of animations. It could be argued that there was an active communication between the students, which did not exist at the beginning of the application process. The following conversation among the students could be considered as an indicator of that fact: Esra; Let's keep each photograph for 0.1 seconds since the number of photographs we have increased. Celal; Exactly, thank you Berk, good of you to say it, otherwise we would be missing many. Esra; Yes, it was, but what we will do now? We have to add these. Melek; Isn't 0.1 seconds too short? Let's make it 1 seconds. Berk; Yes, if we make it 0.1 seconds it will pass through like a jet plane. As could be observed in the conversation among students, students spent effort to come up with a better product and in-group communications improved during the study.

Arithmetic means and standard deviations of pretest and post test scores of each group were calculated to determine the effect of the application on the $21^{\text {st }}$ century learning and innovation skills of the students. t-test was conducted to determine whether the difference between the scores test and control group students obtained in the scale posttest and pretest was significant. Test and control group students' pretest scale score findings are presented in Table 2. 
Table 2. Pre-test score findings for test and control groups on $21^{\text {st }}$ century learning and innovation skills scale

\begin{tabular}{lrrrrrr}
\hline Student Groups & $N$ & $M$ & $s s$ & $t$ & $s d$ & $p$ \\
\hline Experiment Group & 22 & 98.81 & 6.56 & 0.46 & 42 & $>.05$ \\
\cline { 1 - 4 } Control Group & 22 & 98.90 & 6.46 & & & \\
\hline
\end{tabular}

Table 2 demonstrates that there was a difference of .09 points between the mean scores test group students and control groups obtained in the pretest favoring the control group. t-test was applied to group mean scores to determine whether this difference was significant and it was found that $t=0.46$. This result demonstrates that the difference between the arithmetic means of two groups was not significant. To determine the effect of the application on $21^{\text {st }}$ century learning and innovation skills the scale was applied to the students in the test group after the slowmation production process once more. Table 3 demonstrates the comparative results of the scores test group students obtained in pretest and posttest applications.

Table 3. Findings on pre-test post-test scores of test group on $21^{\text {st }}$ century learning and innovation scale

\begin{tabular}{lrrrrrr}
\hline Student Groups & $N$ & $M$ & $s s$ & $t$ & $s d$ & $p$ \\
\hline Experiment Group & 22 & 98.81 & 6.56 & 4.809 & 21 & $<.01$ \\
\cline { 1 - 4 } Control Group & 22 & 102.86 & 5.87 & & & \\
\hline
\end{tabular}

Table 3 demonstrates that $21^{\text {st }}$ century learning and in novation skill levels of participating students was an average of 98.81 points and the standard deviation was 6.56 points, while their posttest skill levels was an average of 102.86 and the standard deviation was 5.87 points. Analysis of the obtained findings demonstrated that there was an approximate increase of 4.05 points and a decrease of 0.69 points in the standard deviation in the $21^{\text {st }}$ century learning and innovation skills scale applied to a student group of 22 individuals. The fact that an increase was observed in the average scores, while there was a decrease in the standard deviation demonstrated a class-wide improvement in the skill. Although the mean and standard deviation values calculated for pretest and posttest applications show an improvement in $21^{\text {st }}$ century learning and innovation skills, t-test was conducted to determine whether this improvement was significant and overall results are displayed in Table 4.

Table 4. Sub-skills pre-test and post-test mean scores t-test results

\begin{tabular}{lrrrrrrr}
\hline Skills & $N$ & $M$ & $s s$ & $s d$ & $t$ & $p$ \\
\hline $\begin{array}{l}\text { Creativity and } \\
\text { Innovation }\end{array}$ & 22 & 1.13 & 1.58 & 21 & 3.36 & $<.01$ \\
\hline $\begin{array}{l}\text { Critical Thinking } \\
\text { and Problem } \\
\text { Solving }\end{array}$ & 22 & 0.22 & 0.42 & 21 & 2.48 & $>.01$ \\
$\begin{array}{l}\text { Collaboration and } \\
\text { Communication }\end{array}$ & 22 & 0.27 & 0.55 & 21 & 2.32 & $>.01$ \\
\hline
\end{tabular}

Table 4 is examined, the development of "creativity and innovation" skills .01 level was significant, the development of "critical thinking and problem-solving" and "communication and cooperation" skills were significant at .05 level. Then, in order to determine the effectiveness of the application of the difference between the average of the scores given by the post-test of the students in both groups it was examined whether meaningful or not. The findings concerning the recent test scores taken from the scale of the experimental and control groups are displayed in Table 5.

Table 5 demonstrates that there was a 3.73 points difference between the post test scores of test and contro group students favoring the test group. t-test was used to determine whether this difference was significant and $t$ value of 2.04 was found. The result demonstrated that the instruction implemented with test and control groups had a significantly different effect on $21^{\text {st }}$ century learning and innovation skills of the students. In other words, it was concluded that slowmation application was effective on the development of students' creativity and innovation, critical thinking and problem solving, collaboration and communication skills.

Table 5. Findings on pre-test and post-test scores of test and control groups in $21^{\text {st }}$ century learning and innovation skills scale

\begin{tabular}{lrrrrrr}
\hline Student Groups & $N$ & $M$ & $s s$ & $t$ & $s d$ & $p$ \\
\hline Experiment Group & 22 & 102.86 & 5.87 & 2.04 & 42 & $<.05$ \\
\cline { 1 - 4 } Control Group & 22 & 99.13 & 6.20 & & & \\
\hline
\end{tabular}

\section{Results, Diccussion and Suggestions}

In the present study that aimed to determine the effect of slowmation application implemented in primary school $4^{\text {th }}$ grade physical sciences course on achievement of $21^{\text {st }}$ century learning and innovation skills, data on the skills that are determined to be used and improved in every stage of the application such as creativity and innovation, critical thinking and problem solving, collaboration and communication skills and findings and results of related studies are discussed. Qualitative and quantitative data demonstrated that students utilized creativity and innovation skills on every stage of slowmation application and they exhibited improvement in the process. This finding was similar to the results of a study by Koçoğlu and Köymen (2003) where the effect of learning environments that students participated as hypermedia designers on the development of their creative thinking at the end of the process was scrutinized. It was determined that students equally utilized skills of curiosity and reading and research on the subject of the creativity and innovation skills and critical thinking and problem-solving skills in the planning phase. It could be argued that, together with these skills, students within the context of the subject they utilized together or those students who researched the subjects they were curious about utilized and developed critical thinking skills as well. This finding was consistent with the finding by Çalışkan (2009) that research-based learning approach had a positive effect on critical thinking skills of the students. While a finding by Akıllı (2012) that there was a medium level positive and significant correlation between students' critical thinking tendencies and their creative level was similar to the findings obtained during the planning stage, it is not possible to claim this relationship based on the findings of the remaining stages. It was determined that students used new technologies in the planning stage and utilized critical thinking and problem-solving skills in the process. The findings of related studies by Serin, Bulut-Serin and Sayglı (2009) and Saygılı (2010) are consistent with the finding that use of educational technology and material in science and technology instruction had positive impact on students' problem-solving skills. Furthermore, in other stages of the study, it was found that despite the fact that students utilized using new technologies skills, they did not use problem solving skills. Thus, it could be argued that using new technologies in the application stages of slowmation production did not have a positive impact on the problem-solving skills of the students. It was determined that students utilized and developed new technology use skill, which was determined as a sub-skill of creativity and innovation skills in the process. A study by Erol and Taş (2012) revealed that there was a significant relationship between the students' frequency of information and communications technology use and their creativity. Thus, it is possible to argue that students' use of creative and innovation skills and utilization of new technologies are effective. It was determined 
that students predominantly utilized critical thinking and problem-solving skills during the planning stage and developed these skills in the process. Furthermore, it was found that students communicated with their peers, asked questions to others and implemented division of labor in the group. This finding is similar to the finding that students collaboratively used and developed problem solving skills during the digital narration process by Hwang and Huang (2012). Thus, it is possible to state that animations that students created in collaboration and communication or digital stories created using similar processes in the learning teaching process develop problem solving skills of the students. The finding by Kurudayıoğlu and Bal (2014) that students' critical thinking skills improved in classes where digital story narrations were used supports the findings of the present study. It could be argued that multimedia tools (slowmation, digital story) created by the students in the process or procured as is contributed to critical thinking skills of the students. It was determined that students predominantly utilized critical thinking and problem solving skills (researching a subject, classification and comparison, giving examples, justification-inference, asking questions, explaining the knowledge using different material, recognizing the connections or contradictions between obtained information, predicting solutions, summarizing the subject) in the planning stage, and utilized classification and comparison skills within the context of critical thinking in the remaining stages. It was concluded that the application provided an opportunity for the students to use their critical thinking and problem-solving skills. This result is similar to the findings in a study by Skinner and Hagood (2008) that digital narrating studies provided an opportunity for the students to express their own experiences and cultural identities and think critically on these. In planning stage, different from other stages, it was found that students utilized and developed critical thinking and problem solving skills and creativity and innovation skills while working in collaboration. This finding is consistent with the result of the study by Yıldız (2012) that collaborative work of students instructed using project-based learning approach increased their creative thinking and problem solving skills. Thus, it could be deducted that problem solving skills of students who work in collaboration are affected positively. The result of a study by Uysal (2009) that instruction conducted with collaborative learning created a significant difference favoring the test group on the development of analysis, assessment, explanation, inference skill, interpretation sub-skills of critical thinking and uniqueness dimension of critical thinking is consistent with the planning stage findings of the present study. It could be argued that groups that worked in collaboration utilized collaboration and communication skills in other stages of the study, while utilizing critical thinking skills only partially or did not used these skills at all.

It was found that students utilized producing solutions, reading and research, imagination, following scientific publications, using new technologies sub-skills of creativity and innovation skills in the narrating stage and developed these skills in the process. In a study by Ersoy and Başer (2012), it is consistent with the finding that scenario-based instruction on producing though and multidimensional thinking skills of creative thinking skills of students. It was determined that communication and collaboration skills that students partially used in planning and narration stages demonstrated a development in the proceeding stages. This finding is similar to the finding by Ming et al. (2014) in their study that showed use of digital narration, which is similar to slowmation, developed communication skills of students. It was determined that students predominantly used collaboration and communication skills in the stages of designing and photographing the models and their transformation into an animation. It was determined that, although the communication was fine between the students, division of labor was not implemented in repro- duction stage. It was determined that students utilized collaboration and communication skills in production and reproduction stages and produced products in the process. It was concluded that, in the project-based slowmation application where a product was created, students utilized and developed communication skills in the process and problems were experienced in division of labor in the later stages of the application occasionally. These results are consistent with the findings by Dağ and Durdu (2011) that the instruction process where project-based learning approach was used also affected the development of students' group work and collaboration skills and there were problems in sharing and implementation of tasks and duties, although in-group communications were fine in group studies. It was determined that students utilized use of new technologies skills in every stage of the application and developed these skills in the process, the application rendered the course more entertaining and supported the learning of students. These findings were similar to results of a study by Brown (2011) that slowmation created by students resulted in students learning both the technology and sciences. It was determined that students used their use of new technologies skill during production and reproduction stages, while they created a product. This result was similar to finding by Kidman, Keast and Cooper (2012) that learners' participation in the process and creating a product using their own knowledge and technological skills during slowmation production process would have different effects on learning. In production and reproduction stages of the application dimension of the study and in the planning stage, which is the first stage where the information is structures, it is possible to argue that students created new products using new technologies and expressed their learning in different manners. Furthermore, in a study by Wang and Zhan (2010), the result that courses realized with digital stories developed technology use and problem solving skills of students supports the study results. Results obtained for digital stories created in processes similar to slowmation creation process are consistent with the study results. In the study, it was determined that students utilized collaboration and communication skills and developed these skills in the process. This finding obtained in the study is consistent with the finding that slowmation production process and presentation of the products enabled social interaction among pre-service teachers by Hoban and Nielsen (2012). The result by Brown, Murcia and Hackling (2013) that applications with multidimensional use of technology such as slowmation, students abode study rules in collaboration and developed their work in collaboration. Furthermore, in a research by Sadik (2008), the finding that production process of digital narration, which is a multimedia learning and teaching tool like slowmation, developed communication and collaboration and technology use skills of students is consistent with the study findings. Brown, Murcia and Hackling (2013) demonstrated that intentional learning-teaching condition designed with slowmation provided an entertaining science education for the students, while promoting the development of their scientific literacy. In the study, it is also possible to argue that students learned by entertainment and conducted research together while working in collaboration, and followed scientific publications in the process, and as a result, developed their scientific literacy. It was determined that students utilized sharing and integrating knowledge skill by sharing the information they researched in the group in production and reproduction stages and in the classroom in planning and narration stages, and student statements demonstrated that the application made the course more entertaining. These results of the study are consistent with the finding by Fleer (2013) that preschool students gathered and shared information during slowmation applications and also they were happy and eager for they participated in the process. 
It was determined in the study by qualitative data and $21^{\text {st }}$ century learning and innovation skills scale that students $21^{\text {st }}$ century skills of learning and innovation during slowmation production process and demonstrated an improvement in determined skills in all dimensions at the end of the process. This finding is similar with the finding that students used and developed $21^{\text {st }}$ Century skills (critical thinking, problem solving, creative thinking, collaboration and communication skills) in the process of creating educational digital movies by Ochsner (2010). In addition, it is similar to the results of a study conducted in early learning environments by Reid, Reid and Ostachevski (2013) that works created by hand by students based on constructivist theory could be applied to develop $21^{\text {st }}$ Century skills of learners. The results of a study by Hayes (2003) that video production process promoted collaboration among pre-service teachers, developed their critical thinking skills, promoted their creativity and resulted in an entertaining learning experience support the findings of the current study. The findings of the study by Czarnecki (2009) that digital stories produced in a process similar to slowmation production process had positive effect on $21^{\text {st }}$ century skills of students support the findings of the present study. Furthermore, the finding in a study by Talib, Norishah and Zulkafly (2014) that collaborative presentations by students using multimedia tools supported their critical and creative skills is consistent with the findings of the study. Thus, it could be argued that students' presentation of the products they created in the classroom supported their critical thinking and creativity and contributed to development of these skills. In the study, classroom teacher stated that more time was needed for the application to be more successful and effective. The findings in a study by Karakoyun (2014) that digital narration activities created in processes similar to slowmation production process developed $21^{\text {st }}$ century skills of students and sufficient time was needed for the application support the findings of this study. The result by Kotluk and Kocakaya (2015) that students developed learning and innovation skills in the digital narration process since they researched on determined subjects is consistent with the study results. It is possible to argue that students utilized and developed their learning and innovation skills (creativity and innovation, critical thinking and problem solving, collaboration and communication) in the process of production of multimedia learning and teaching tools (digital story, slowmation, etc.).

As a result, SMA production process is an application where students utilize and, in the process, develop creativity and innovation, critical thinking and problem solving, collaboration and communication skills expressed as learning and innovation skills. Students utilized these skills in every stage of the application at a certain extent. It is possible to claim that certain specific skills supported each other in the process. A sample of slowmation production process using basic level technologies was reflected in the study. It is possible for students to adapt the animations they created in the class to different courses or to use this application in their social lives.

\section{References}

Akıllı, N. (2012). Ilköğretim sekizinci sınıf öğrencilerinin eleştirel düşünme eğilimleri ve yaratıcılık düzeylerinin değerlendirilmesi (Unpublished Master Thesis). Sütçü İmam Üniversitesi, Kahramanmaraş.

Akpınar, E., Aktamış, H. \& Ergin, Ö. (2005). Fen bilgisi dersinde eğitim teknolojisi kullanılmasına yönelik öğrenci görüşleri. The Turkish Online Journal of Educational Technology 4(1), 93-100.
Alkan, M. (2011). Fen bilgisi eğitiminde teknoloji entegrasyonu. S.Perkmez \& E. Tezci.(Eds), Eğitimde teknoloji entegrasyonu (pp.109-121). Ankara: Pegem.

Atılboz, N. G. (2004). Lise 1. sınıf öğrencilerinin mitoz ve mayoz bölünme konuları ile ilgili anlama düzeyleri ve kavram yanılgılar. Gazi Üniversitesi Eğitim Fakültesi Dergisi, 24(3), 147-157.

Brown, J. (2011). The impact of student created slowmation on the teaching and learning of primary science (Unpublished Master Thesis). University of Edith Cowan, Australia.

Brown, J., Murcia, K. \& Hackling, M. (2013). Slowmation: A multimodal strategy for engaging children with primary science. Teaching Science, 59(4), 14-20.

Creswell, J. W. \& Clark, V. L. P. (2006). Choosing a mixed methods design. Designing and conducting mixed methods research içinde. Thousand Oaks: Sage Publications.

Creswell, J. W. \& Clark, V. L. P (2007). Designing and conducting mixed methods research. London - New Delhi: Sage Publication.

Creswell, J.W. (2009). Research design: qualitative, quantitative, and mixed methods approaches. USA: Sage.

Czarnecki, K. (2009). How digital storytelling builds $21^{\text {st }}$ century skills. Retrieved from www. alatechsource.org.

Çalışkan, H. (2009). Sosyal bilgiler öğretiminde araştırmaya dayalı öğrenme yaklaşımının eleştirel düşünme becerisine etkisi. Kastamonu Eğitim Dergisi, 17(1), 57-70.

Dağ, F. \& Durdu, L. (2011). Öğretmen adaylarının proje tabanlı ögrenme sürecine yönelik görüşleri. Retrieved from http://web.firat.edu.tr/icits2011/papers/27754.pdf

Dede, C. (2009). Comparing frameworks for $21^{\text {st }}$ century skills. Retrieved from http://www.watertown.k12. ma.us/dept/ed_tech/research/pdf/ChrisDede.pdf

Efendioğlu, A. (2012). Çoklu ortam benzetimlerinin fen öğretiminde uygulanması ve öğretmen adaylarının bilişsel ve duyuşsal özelliklerine etkisinin incelenmesi (Unpublished Phd Dissertation). Mersin Üniversitesi, Mersin.

Erol, O. \& Taş, S. (2012). MYO Öğrencilerinin bilgi ve iletişim teknolojilerini kullanma sıklıkları ile yaratıcılık algıları arasındaki ilişkinin incelenmesi. Mehmet Akif Ersoy Üniversitesi Sosyal Bilimler Enstitüsü Dergisi, 4(7), 82-104.

Ersoy, E. \& Başer, N. (2012). Olasılık konusunun senaryo ile öğretim süreci sonunda öğrencilerin yaratıc düşünme becerilerindeki değişimi. Retrieved from http://kongre.nigde.edu.tr/xufbmek/dosyalar/ tam_metin/pdf/2223-02_05_2012-23_34_15.pdf

Fleer, M. (2013). Affective imagination in science education: determining the emotional nature of scientific and technological learning of young children. Research Science Education, 43(5), 2085-2106.

Hayes, M.T. (2003). The pleasure of movie making. Journal of Computing in Teacher Education, 19(3), 82-86.

Hoban, G. (2005). From claymation to slowmation: A teaching procedure to develop students' science understandings. Teaching Science: Australian Science Teachers Journal, 51(2), 26-30. 
Hoban, G. \& Ferry, B. (2006). Teaching science concepts in higher education classes with slow motion animation (slowmation). E-Learn 2006 World Conference on E Learning in Corporate, Government, Healthcare \& Higher Education, Chesapeake, VA, USA: Association for the Advancement of Computing in Education.

Hoban, G. (2007). Using slowmation to engage preservice elementary teachers in understanding science content knowledge. Contemporary Issues in Technology and Teacher Education, 7(2), 1-9.

Hoban, G. (2009). Facilitating learner-generated animations with slowmation. In L. Lockyer, S. Bennett, S. Agostino \& B. Harper (Eds.) Handbook of research on learning design and learning objects:Issues, applications, and technologies (pp. 313-330). Hershey, PA: IGI Global

Hoban, G., Loughran, J. \& Nielsen, W. (2011). Slowmation: Preservice elemantary teachers representing science knowledge through creating multimodal digital animations. Journal of research in science teaching, 48(9), 985-1009.

Hoban, G.\& Nielsen, W. (2012). Learning science through creating a 'slowmation': a case study of preservice primary teachers. International Journal of Science Education, 1-28.

Hoban, G. \& Nielsen, W. (2013). Learning, explaining and communicating science with student-created blended media. Retrieved from http://openjournals.library. usyd.edu.au/index.php/IISME/issue/view/606

Hung, C., M., Hwang, G. J. \& Huang, I. (2012). A Project-based digital storytelling approach for improving students' learning motivation, problem-solving competence and learning achievement. Educational Technology \& Society, 15(4), 368-379.

Karakoyun, F. (2014). Çevrimiçi ortamda oluşturulan dijital öyküleme etkinliklerine ilişkin öğretmen adayları ve ilköğretim öğrencilerinin görüşlerinin incelenmesi (Unpublished Phd Dissertation). Anadolu Üniversitesi, Eskişehir.

Keast, S., Cooper, R., Berry, A., Loughran, J. \& Hoban, G., 2010, Slowmation as a pedagogical scaffolding for improving science teaching and learning. International Journal of Science and Mathematics 2(1), 1-15.

Kervin, K. (2007). Exploring the use of slow motion animation (slowmation) as a teaching strategy to develop year 4 students' understandings of equivalent fractions. Contemporary Issues in Technology and Teacher Education, 7(2), 100-106.

Kidman, G., Keast, S., \& Cooper, R. (2012). Responding to the 5rs: An alternate perspective of slowmation. Teaching Science: The Journal of the Australian Science Teachers Association, 58(2), 24-30.

Koçoğlu, Ç. \& Köymen, Ü. (2003). Öğrencilerin hiperortam tasarımcısı olarak katıldığı öğrenme çevresinin yaratıcı düşünmeye etkisi. The Turkish Online Journal of Educational Technology, 2(3), 127-136.

Kotluk, N. \& Kocakaya, S. (2015). 21.yüzyıl becerilerinin gelişiminde dijital öykülemeler: ortaöğretim öğrencilerinin görüşlerinin incelenmesi. Journal of Research in Education and Teaching, 4(2), 354-363.

Kurudayıoğlu, M. \& Bal, M. (2014). Ana dili eğitiminde dijital hikâye anlatımlarının kullanımı. Sakarya Üniversitesi Eğitim Fakültesi Dergisi, 28, 81- 99.
Millî Eğitim Bakanlığı Talim Terbiye Kurulu Başkanlığı (2005). Illköğretim fen ve teknoloji dersi 6, 7 ve 8. sinıf ögretim programı. Ankara: Devlet Kitapları Basım Evi.

Ming, T. S., Sim, L. Y., Mahmud, N., Kee, L. L., Zabidi, N. A. \& Ismail, K. (2014). Enhancing 21 ${ }^{\text {st }}$ century learning skills via digital storytelling: Voices of Malaysian teachers and undergraduates. Procedia - Social and Behavioral Sciences, 118, 489- 494.

Ochsner, K. (2010). Lights, camera, action research: the effects of didactic digital movie making on students' twenty-first century learning skills and science content in the middle school classroom (Unpublished Phd Dissertation). University of Arizona State, Arizona.

Palinkas, L. A. , Horwitz, S. M. , Green, C.A., Wisdom, J. P., Duan, N. \& Hoagwood, K. (2015). Purposeful Sampling for Qualitative Data Collection and Analysis in Mixed Method Implementation Research. Adm Policy Ment Health. 42(5), 533-544.

Partnership for $21^{\text {st }}$ Century Skills. (2009) Framework for $21^{\text {st }}$ century learning. Retrieved from http://www. p21.org/our-work/p21-framework.

Plano Clark, V. L., Creswell, J. W., Green, D. O. \& Shope, R. J. (2008). Mixing quantitative and qualitative approaches: An introduction to emergent mixed methods research. HesseBiber \& P. Leavy (Eds.) The handbook of emergent methods (pp. 363-387). New York: Guilford Press.

Reid, D., Reid, E.\& Ostashewski, N. (2013). Combining iPads and slowmation: Developing digital storytellers in an early learning environment. World Conference on Educational Media and Technology Retrieved from http://www.editlib.org/p/112164.

Sadik, A. (2008). Digital storytelling: A meaningful technology-integrated approach for engaged student learning. Educational Technology Research and Development, 56(4), 487-506.

Saygılı, G. (2010). Öğretim teknolojilerinin fen ve teknoloji dersinde kullanımının ilköğretim öğrencilerinin problem çözme becerilerine öğrenme ve ders çalışma stratejilerine üst düzey düşünme becerilerine fen ve teknoloji dersine yönelik tutumlarına ve ders başarısına etkisinin incelenmesi. (Unpublished Phd Dissertation). Dokuz Eylül Üniversitesi, İzmir.

Serin, O., Bulut-Serin, N. \& Saygil, G. (2009). The effect of educational technologies and material supported science and technology teaching on the problem solving skills of 5 the grade primary school student. Retrieved from http://www.sciencedirect.com/science/article/pii/S1877042809001189

Skinner, E. \& Hagood, M. (2008). Developing literate identities with English language learners through digital storytelling. The Reading Matrix, 8(2), 12-38.

Talib, O., Norishah, T.P. \& Zulkafly, N.A. (2014). Understanding the wonders of science through creative play. Retrieved from http://www.sciencedirect.com/science/article/pii/S1877042814036696

Tutkun, Ö. F. (2010). 21.yüzyılda eğitim programının felsefi boyutları. Gazi Üniversitesi Gazi Eğitim Fakültesi Dergisi, 30(3), 993-1016.

Uysal, M.E. (2009). illköğretim türkçe dersinde işbirlikli öğrenmenin erişi, eleştirel düşünce ve yaratıcılık becerilerine etkisi. (Unpublished Phd Dissertation). Dokuz Eylül Üniversitesi, İzmir, 
Ürey, M.\& Çepni S. (2014). Fen temelli ve disiplinlerarası okul bahçesi programının öğrencilerin fen ve teknoloji dersine yönelik tutumları üzerine etkisinin farklı değişkenler açısından değerlendirilmesi. Ondokuz Mayıs Üniversitesi Eğitim Fakültesi Dergisi, 33(2), 537-548.

Wagner, T. (2008). Rigor redefined. Educational Leadership, 68(2), 20-24.

Wang, S. \& Zhan, H. (2010). Enhancing teaching and learning with digital storytelling. International Journal of Information and Communication Technology Education, 6(2), 76-87.

Yıldııım, A. \& Şimşek, H. (2008). Sosyal bilimlerde nitel araştırma yöntemleri. Ankara: Seçkin Yayınları.

Yıldız, Z. (2012). Proje tabanlı öğrenme yaklaşımının orta ögretim öğrencilerinin yaratıcı düşünme problem çözme ve akademik risk alma düzeylerine (Unpublished Master's Thesis). Gazi Üniversitesi, Ankara. 